\title{
Lojistik Maliyetlere Göre Teslim Tarihi Belirleme ve Bir Karar Modeli Önerisi
}

\author{
Cemal Aktürk ${ }^{*}$ \\ ${ }^{1}$ Kilis 7 Aralık Üniversitesi, Mühendislik Fakültesi, Bilgisayar Mühendisliği Bölümü, Kilis, Türkiye (ORCID: 0000-0003-3764-3862)
}

(Illk Geliş Tarihi 18 Mart 2019 ve Kabul Tarihi 19 Nisan 2019)

(DOI: $10.31590 /$ ejosat.541481)

ATIF/REFERENCE: Aktürk, C., (2019). Lojistik Maliyetlere Göre Teslim Tarihi Belirleme ve Bir Karar Modeli Önerisi. Avrupa Bilim ve Teknoloji Dergisi, (16), 1-7.

$\ddot{O} \mathbf{z}$

Siparişe göre üretim yapan firmalarda siparişlerin teslim tarihi belirleme süreci iyi yönetilmediği durumlarda çeşitli sorunlarla karşılaşılmaktadır. Müşterilerin sipariş talebine karşılık olarak üretici tarafından teklif edilen sipariş teslim tarihi, hem müşteriyi memnun etmeli hem de üretici firmanın kârlılı̆̆ını korumalıdır. Müşteriler tarafından talep edilen teslim tarihleri ile firmaların önerdiği teslim tarihlerinin arasındaki zaman farkının beklentileri ve planlamaları aşması durumunda tedarik zinciri içerisinde çeşitli anlaşmazlıklar ve maliyetler ortaya çıkmaktadır. Siparişleri talep tarihinden geç üretmenin getirdiği anlaşmazlıklara ek olarak, talep tarihinden erken üretilerek stokta bekletilen ürünler için de hesaplanmayan çeşitli lojistik maliyetler doğmaktadır. Depolama, elleçleme ve vade farkı tutarları bu maliyetlerden bazılarıdır. Depolama maliyetleri; depo kirası ile ürün sigorta bedellerinden oluşur. Elleçleme maliyeti bekletilen sipariş için fazladan yapılacak yükleme ve boşaltma işleminde harcanan işçilik ücreti ve iş makinelerinin tüketimlerini kapsar. Vade farkı ise hammadde için vaktinden önce ödenen sermaye gideri üzerinden hesaplanır. Yapılan çalışmada, bu maliyetler ayrıntılı olarak denklemlerle ifade edilmiştir. Sonrasında önerilen doğrusal fonksiyonlar ile lojistik maliyetler için amaç fonksiyonu tanımlanmıştır ve amaç fonksiyonuna göre sıralanarak üretilecek siparişler için ortaya çıkan maliyetler gösterilmiştir. Ayrıca bu maliyetlerin ürün fiyatına yansıtılması veya işletmenin kârlılığını düşürmemesi için üretici ve müşteri arasında hem teslim tarihi hem de ürün fiyatı üzerinden pazarlık yapmanın sözkonusu olabileceği vurgulanmaktadır. Önerilen karar modeli, daha önce teslim tarihi çalışmalarında dikkat edilmeyen, lojistik maliyetleri içerdiğinden dolayı yeni ve farklı bir yaklaşım sunmaktadır. Bu sayede çalışmada önerilen karar modeli herhangi bir yazılım geliştirme ortamında programlanarak satış pazarlama birimleri için kritik kararları vermede yardımcı olacak yararlı karar destek sistemleri geliştirilebilir. Ayrıca sonraki çalışmalar için araştırmacılara lojistik maliyetleri de içeren karar destek sistemleri için yeni bir yol açılmaktadır.

Anahtar Kelimeler: Karar Destek Sistemi, Teslim Tarihi, Lojistik Maliyetleri, Stok Maliyeti.

\section{Determination of Due-Date and A Decision Model Proposal By Logistics Costs}

\begin{abstract}
According to the make-to-order companies, when the due date determination process is not managed well, various problems are encountered. The order due date offered by the manufacturer in response to the customers' order request should both satisfy the customer and protect the manufacturer's profitability. In case the time difference between the due dates requested by the customers and the due dates suggested by the companies exceed the expectations and planning, various disputes and costs occur within the supply chain. In addition to the disputes caused by the late production of orders, there are various logistic costs which are not calculated for the products which are produced in stock and which are kept early in the demand date. Storage, handling and overdue amounts are some of these costs. Storage costs consist of warehouse rent and product insurance costs. The cost of handling covers the labor costs spent on loading and unloading, as well as the consumption of work machines. The overdue amount is calculated over the
\end{abstract}

${ }^{*}$ Sorumlu Yazar: Kilis 7 Aralık Üniversitesi, Mühendislik Fakültesi, Bilgisayar Mühendisliği Bölümü, Kilis, Türkiye, ORCID: 0000-0003-37643862, cakturk@kilis.edu.tr 
pre-paid capital expense for raw materials. In this study, these costs are expressed in detail by equations. The objective function for the proposed linear functions and logistics costs is then defined and the costs for the orders to be produced are listed according to the objective function. Furthermore, it is emphasized that both the due date and the price of the product can be negotiated between the manufacturer and the customer in order to reflect these costs to the product price or not to decrease the profitability of the enterprise. The proposed decision model offers a new and different approach because it contains logistics costs which are not considered in the studies of the due date. In this way, the proposed decision model in the study can be programmed in any software development environment and useful decision support systems can be developed to assist in making critical decisions for sales marketing units. In addition, a new way for the decision support systems, including logistics costs, is opened to researchers for subsequent studies.

Keywords: Decision Support System, Due Date, Logistics Costs, Inventory Cost.

\section{Giriş}

Üretim işletmeleri, ürünlerini ya müşteri taleplerini karşılamak için siparişe göre üretirler ya da belirli bir satış öngörüsü ile üreterek stok yaparlar. Bu üretim yöntemi sektöre ve ürüne göre değişiklik gösterebilir. Örnek vermek gerekirse her müşteriye hitap eden, belirli bir pazarlama ağı olan ürünler önceki dönemsel satış miktarları göz önünde bulundurularak tahmini satış miktarları hesaplanıp bu miktara göre üretilip stoklanırken, müşterinin isteğine göre değişkenlik gereken ürünlerde bu yolu izlemek risklidir. Çünkü bir müşterinin talep ettiği ürün özelliklerini bir başka müşteri kabul etmeyebilir. Ayrıca son kullanma tarihine sahip ürünlerin üretildikten sonra stokta beklemesi de ürünün bozulma ihtimaline karşın oldukça riskli bir durumdur. Bu tür ürünlerde sektörün pazar talebinin takip edilmesi oldukça önemlidir.

Siparişe göre üretim yapan firmalar, kendilerine gelen müşteri taleplerini değerlendirirken tedarik zincirindeki tüm süreçleri göz önünde bulundurarak müşterilerine bir teslim tarihi önerirler. Bu teslim tarihini sunarken siparişe konu ürünün stok durumu, eksik miktarlar için hammadde ihtiyacı ve hammadde termin süresi, üretim süresi ve sevkiyat süresi gibi süreçler iyi hesaplanmalıdır. Sonuç olarak müşterilere sunulacak ürün teslim tarihi, müşterinin beklentisini karşılamalı ve memnuniyetini sağlamalıdır. Ayrıca müşterinin talep ettiği tarihten daha önce bir tarih için ürünleri üreterek bekletmek de işletmeye çeşitli maliyetler ve riskler getirecektir. Çünkü talep tarihinden önce hazır hale getirilen ürünler; depolama, elleçleme (yükleme-boşaltma), erken hammadde temininden dolayı karlılığın azalması vb. birçok lojistik maliyetleri de beraberinde getirir. Yapılan satışın gelire ve kara dönüşmesi beklenirken bu şekilde öngörülmeyen maliyetler işletmeye gizli maliyetler getirdiğinden dolayı genel olarak işletmelerin karlılığını doğrudan etkiler.

Literatürdeki çalışmalara bakıldığında, siparişler için teslim tarihleri hesaplanırken talep edilen tarihe göre erken ve geç durumda kalan teslim tarihlerinin her zaman bir maliyet de ürettiği gözlenmektedir. Hatta bazı durumlarda gelen siparişler, kabul veya ret kararı verilmeden önce değerlendirilir ve kârlı bulunan siparişler kabul edilir. Guhlic ve arkadaşları (2015), müşterilerden gelen siparişlerin talep edilen tarihine göre değerlendirilip karlı bulunması durumunda kabul edildiği, diğer durumlarda ret kararı verildiği olasılık tabanlı bir karar modeli geliştirmiştir. Bir başka çalışmada araştırmacılar tüm işlerin gecikmesinden kaynaklanan toplam ceza değerini iyileştirmek için yaptıkları çalışmada en uzun işlem süresinin ilk önce üretilmesi yöntemiyle en az ceza değerini elde etmişlerdir (Jagan vd., 2015). Demir ve arkadaşları (2015) ise çizelgeleme çalışmalarında hem erken hem de geç kalan teslim tarihleri için siparişlerin cezalandırmalarını varsaymışlardır. Low ve arkadaşları (2015) ise çalışmalarında planlı bakım periyotlarını da göz önünde bulundurarak her işin tamamlanma zamanlarının mutlak sapmalarını minimize etmeyi amaçlamışlardır. Aynı ekip bir diğer çalışmalarında hem toplam erkenliliği hem de toplam gecikmeyi minimize etmeye çalışmıştır (Low vd., 2016), çünkü bir siparişi vaktinden erken teslim etmek veya üretip bekletmek de çeşitli maliyetler doğurmaktadır. Bir diğer çalışmada çift teslim tarihi kullanılarak geciken işlerde gecikilen süreye göre iki farklı gecikme maliyeti uygulanıp toplam ağırlıklı gecikme azaltılmaya çalışılmıştır (Çakar vd., 2015). Baker ve Trietsch (2015), sıralanan işlerin geç kalmaması amacıyla stokastik tem makineli bir model için formül çalışması geliştirmiştir. 2016 yılında yapılan bir çalışmada ise pazarlama, planlama ve lojistik birimlerinin tüm faaliyetleri birlikte değerlendirilerek gecikme ile ilgili maliyetlerin azaltılması sorunu araştırılmıştır (Assarzadegan ve Barzoki, 2016). Teslim tarihi atama problemi yine maliyet odaklı çalışılmış olup toplam geciken iş sayısı ve teslim tarihi atama maliyetlerinin minimize edilebileceği gösterilmiştir (Shatbay vd., 2016; Zhao, 2016; Drwal, 2018). Bir diğer çalışmada teslim tarihi performans kriterleri olarak gecikme, göreli gecikme, zamanlama güvenilirliği gibi parametrelerin birbiri arasındaki ilişkiler analiz edilmiştir (Schäfer vd., 2016). Li ve Chen (2017) tek makineli bir planlama ortamı için teslim tarihi problemine getirdikleri çözüm önerisinde toplam erkenlilik cezalarını içeren bir maliyet fonksiyonunu minimize etmeyi amaçlamışlardır. Bir başka çalışmada yeni eklenen bir siparişin toplam maliyetinin, mevcut iş yükü çizelgesiyle karşılaştırıldığı bir karar mekanizması kullanılarak toplam maliyet azaltılmıştır (Nurainun vd., 2016). Üretim süresinin uzamasına bağlı olarak ortaya çıkan stok maliyeti ve bakım maliyetinin minimize edilmesi çalışılmıştır (Zahedi vd., 2016). Farklı bir çalışmada siparişler en erken bitiş sürelerine göre sıralanarak işlerdeki gecikmenin telafi edilip edilemeyeceği gösterilmiştir (Lödding ve Piontek, 2017). Siparişlerin doğrusal bir fonksiyon ile sıralanarak yapılacak teslim tarihi atamaları ile pazarlama birimleri için inovatif bir karar modeli önerilmiştir (Aktürk ve Gülseçen, 2017). Aynı araştırmacılar tarafından siparişlerin altı farklı karar modeli ile sıralanarak teslim tarihlerinin atandığı çok kriterli ve çok yöntemli bir karar destek sistemi önerilmiştir (Aktürk ve Gülseçen, 2018b).

Lojistik; mal veya hizmet üretimi yapan işletmelerde hammaddenin temin edilerek üretime alınmasından, ürünlerin dağtım kanallarıyla son kullanıcıya ulaşmasına kadar yapılan tüm faaliyetlerin içerisindeki sevk ve yönetimini sağlayan bir süreçler bütünüdür (Şen, 2014). Başarılı lojistik faaliyetler, maliyetleri düşürür, süreçleri hızlı işletir ve müşteri memnuniyetini sağlar (Ceran ve Alagöz, 2007). Üretim işletmeleri için maliyet açısından incelemek gerekirse, lojistik maliyetler; üretilen veya satılan malların maliyetinden hemen sonra ikinci sırada yer almaktadır (Şen, 2014). Dolayısıyla lojistik maliyetlerin üretim işletmelerinin tüm iş süreçleri içerisindeki payı göz önünde bulundurulursa firmalar maliyetlerini ve kârlılıklarını kontrol edebilir. Bunun için sipariş sıralama, üretim planlama ve sevkiyat gibi tüm iş süreçlerinde yapılacak araştırmalar ve bulunacak yeni yaklaşımlar doğrudan 
firmaların maliyetlerini azaltmaya fayda sağlayacağı için aynı zamanda firmaların kârlılıklarını ve pazardaki paylarını arttırmaları için de önem arz etmektedir.

Buraya kadar anlatılan çalışmalara bakıldı̆̆ında, sipariş sıralama, teslim tarihi atama ve çizelgeleme problemlerinde erken üretilen veya talep tarihine göre geç duruma düşen siparişler için depolama, elleçleme (yükleme-boşaltma) ve hammadde teminindeki vade farkından dolayı oluşan lojistik maliyetlerinin teslim tarihi hesaplamalarında dikkate alınmadığı, amaç veya maliyet fonksiyonlarına dâhil edilmediği gözlemlenmiş̧ir. Bu sebeple yapılan çalışmada, siparişe göre üretim yapan işletmelerin teslim tarihi belirleme problemine bir çözüm olarak lojistik maliyetler perspektifinde bir karar modeli önerilmektedir. Bu kapsamda işletmeye gelen siparişler için her siparişin üretim süreleri baz alınıp müşterilerin talep ettikleri teslim tarihleri de dikkate alınarak bir sipariş teslim tarihi hesaplanacaktır. Lojistik maliyetler olarak, hesaplanan teslim tarihlerinin ilgili siparişi talep eden müşterinin talep tarihi ile ilişkilendirilmesi neticesinde erken veya geç durumda kalan siparişler için doğacak depolama, elleçleme ve hammadde temininden doğacak vade farkı maliyetleri kullanılmıştır.

\section{Materyal ve Metot}

\subsection{Karar Modeli Önerisi}

Lojistik maliyetlerini oluşturan kriterleri matematiksel model olarak ifade edebilmek adına yapılan literatür araştırmalarında bu maliyetlerin depolama, işgaliye, elleçleme gibi maliyetlerden meydana geldiği anlaşılmaktadır (Ceran ve Alagöz, 2007; Şen, 2014). $\mathrm{Bu}$ maliyetlerin günlük hayatta uygulanabilirliği ve gerçek karşlıklarını araştırmak için uluslarası ticaret ve lojistik uzmanı, endüstri mühendisi, muhasebe uzmanı ve işletme yöneticilerinden oluşan beş uzman ile yüzyüze görüş̧me sağlanmıştır. Yapılan görüşmelerde literatürde lojistik maliyetler olarak sınıflandırılan ve yukarıda bahsedilen maliyetlerin gerçek işletme ortamlarında da geçerli olduğu her bir uzmandan alınan görüşlerle teyit edilmiştir. Dahası, sektöre ve ürüne özel daha farklı lojistik maliyetlerinin de bulunduğu sonuçlarına ulaşılmışıı. Örneğin ithalat-ihracat faaliyeti yürüten üreticilerde üretimin veya sevkiyatın beklemesinden dolayı döviz fiyatlarındaki değişkenliklerden doğacak maliyetler bulunmaktadır. Benzer şekilde gida üreticileri için ürünlerin belirli bir son kullanma tarihi olduğundan stokta bekleyen ürünler için soğuk hava depolarının çalı̧̧ma maliyeti ve ürünün bozulma riski bulunmaktadır. Kimyevi madde sınıfında tehlikeli, patlayıcı madde üreten işletmeler için iş güvenliği adı altında depolanan ürünler için ekstra maliyet kalemleri bulunmaktadır. Ancak bu çalışmada belirli bir sektör kısııında bir çalışma yürütülmediğinden dolayı genel bir model önerisi için bu tür sektöre özel kriterler göz önünde bulundurulmamıştır.

Uzman görüşlerinden elde edilen lojistik maliyet kriterler, bu maliyetleri yönetebilmek için ayrıntıları Denklem 1'de belirtilen doğrusal $\mathrm{F}$ fonksiyonu ile tanımlanmıştır. Denklem 1'de gösterilen I alt fonksiyonu depolama maliyetini ifade etmek için kullanılmıştır. T fonksiyonu elleçleme maliyetini, $\mathrm{M}$ ise hammadde teminindeki vade farkından doğacak maliyeti ifade etmektedir. $\mathrm{W}_{1}, \mathrm{~W}_{2}, \mathrm{~W}_{3}$ ise bu fonksiyonların amaç fonksiyonu olan $\mathrm{F}$ içerisindeki ağırlık katsayılarını belirlemekte kullanılır. Ağılık katsayılarının toplamı 1 olmalıdır. Bu ağırlık katsayıları karar modelinden istifade edecek üreticilerin sektörüne, firmanın yapısına, amaçlarına ve yöneticilerinin görüşlerine göre değişkenlik arz edeceğinden dolayı çalışmada ağırlık katsayılarının değerleri belirtilmemiştir.

$$
F(i)=W_{1} \cdot \mathrm{I}(\mathrm{i})+W_{2} \cdot \mathrm{T}(\mathrm{i})+W_{3} \cdot \mathrm{M}(\mathrm{i})
$$

Depolama maliyeti (I fonksiyonu) ayrıntıları Denklem 2'de belirtildiği üzere, kendi içerisinde farklı ağırlıklarda ürün sigorta ve işgaliye gibi maliyetleri kapsamaktadır. $\mathrm{W}_{\mathrm{i}}$ 'ler alt fonksiyonların ağırlık katsayılarını belirtir ve toplamları 1 olmalıdır. Her bir sipariş için hesaplanacak depolama maliyetinde $\mathrm{G}$ fonksiyonu her bir sipariş için denklem 3 'te ayrıntıları gösterildiği gibi hesaplanacak günlük sigortalama maliyetidir. Denklem 3'te gösterilen A; ilgili sipariş tutarını, k; sigorta firmalarından temin edilecek ve teminat tutarını hesaplamada kullanılacak sigorta maliyet katsayısını, d ise ürünün sigortalanacak gün sayısını belirtmektedir.

$$
\begin{aligned}
& I(i)=W_{i 1} \cdot \mathrm{G}(\mathrm{i})+W_{i 2} \cdot \mathrm{S}(\mathrm{i}) \\
& G(i)=k * \mathrm{~A}(\mathrm{i}) * \mathrm{~d} \\
& S(i)=Y U K A R I Y U V A R L A(\mathrm{OQ} / \mathrm{UPQ} / \mathrm{QCPM} 2)) * \mathrm{P} * \mathrm{~d}(4)
\end{aligned}
$$

Denklem 4'te belirtilen $\mathrm{S}$ fonksiyonu ise depolama maliyetlerinden, kiralık depo kullanan üretici için hesaplanan günlük işgaliye bedelidir. S fonksiyonunun parametrelerini tanımamak gerekirse; OQ; siparişin toplam miktarını, UPQ; her bir birim ambalaja sığan ürün miktarını, QCPM2; kiralanan depoda metrekareye düşen istiflenebilecek ambalaj sayısını, $P$ ise kiralanan deponun günlük metrekare kira ücretini ifade etmektedir. Burada dikkat edilmesi gereken nokta OQ/UPQ/QCPM2 ifadesinin sonucunun küsuratlı çıkması durumunda en yakın büyük tamsayıya yuvarlanması gerektiğidir. $\mathrm{Bu}$ durum excel programında kullanılan YUKARIYUVARLA fonksiyonu ile denklemde belirtilmiştir.

Teslim tarihinden önce üretilip depolanacak ürün için fazladan elleçleme işlemi yapılacaktır. Bu işlem süreci de gizli bir maliyete sahiptir. Denklem 5'te gösterilen T fonksiyonu fazladan yapılan elleçleme işleminin doğurduğu maliyetleri göstermektedir. Denklem 5 incelenecek olursa; R; dakika cinsinden elleçleme işlem süresini, C; elleçleme işlemiyle iştigal olan personel sayısını, E; dakika cinsinden iş̧̧ilik ücretini, FC ise elleçlemede kullanılan forklift $\mathrm{vb}$ iş makinelerin dakikadaki yakıt tüketiminin TL cinsinden ifadesidir. İş makinasının markasına kapasitesine motor hacmine göre değişkenlik gösteren yakıt tüketimi, ilgili makinenin fabrika verileri üzerinden hesaplanarak dakikadaki tüketimi hesaplanabilmektedir.

$$
T(i)=\mathrm{R} *(\mathrm{C} * \mathrm{E}+\mathrm{FC})
$$


Hammaddenin erken alınmasından dolayı işletmenin dolaylı yoldan karşıladığı vade farkı ile ilgili fonksiyon olan $\mathrm{M}$ fonksiyonunun ayrıntıları Denklem 6'da gösterilmektedir. Buradaki V değişkeni günlük vade farkı oranını, pr ise sipariş tutarlarındaki ortalama kar oranını ifade eder. Sipariş tutarını ifade eden A fonksiyonundan ortalama kar oranına denk gelecek kar tutarı çıkarılarak hammaddenin maliyeti hızlıca hesaplanır. Hammadde maliyetinin net bilindiği durumlar için bu hesaplamaya gerek kalmadan doğrudan ilgili parantez içinde kullanılabilir. Burada belirtilen kar oranı aslında aynı zamanda alınan hammaddeye kazandırılan katma değeri de ifade eder. Netice olarak belirli bir gün sayısı kadar vaktinden erken üretilen siparişin hammaddesinin erken temininden ve hammaddeye erken bağlanan sermayeden dolayı gizli bir maliyet olarak vade farkı hesaplanır. Çünkü hesaplanan sürede ürünü teslim etmek için hammadde bağlantısı daha geç yapılabileceğinden dolayı hammaddeye vaktinden erken sermaye bağlanması bu şekilde gizli bir vade maliyetini de beraberinde getirmektedir.

$$
M(i)=\mathrm{d} * \mathrm{~V} *(\mathrm{~A}(\mathrm{i})-\mathrm{A}(\mathrm{i}) * \mathrm{pr})
$$

Nihai durumda maliyet fonksiyonu olan $\mathrm{F}$ amaç fonksiyonunun minimize edilmesi veya $\mathrm{F}$ fonksiyon değeri daha düşük olan siparişlerin işletmeye lojistik maliyetleri daha az olacağı için üretim programına dâhil edilecek planlamada önceliklendirilmesi hedeflenmektedir. Bunun için her ne kadar F fonksiyonu içerisindeki I, T ve M fonksiyonlarının değer kümeleri TL cinsinden maliyet ifade etse de, maliyet kalemlerinin birbiri üzerindeki etkileri ağırlık katsayılarına göre hesaplamalarda oranlanabilir, hatta kriterler için tüm sipariş havuzu verileri içinde normalizasyon işlemi yapılarak kriterler arasındaki farklılıklar ortadan kaldırılabilir.

Normalizasyon işlemi; her bir siparişteki ilgili kriter değerinin tüm siparişler içerisindeki kriter değerleri en iyi olan siparişin değerine bölünerek oranlanması işlemidir. Eğer kriter maksimize edilecek bir kriter ise en büyük değere sahip olan alternatif en iyi kriter değerine sahip demektir. Tersi olarak minimize edilecek maliyet benzeri bir kriter ise en küçük maliyet değerine sahip olan alternatif en iyi kriter değerine sahiptir. Normalizasyon işleminin her kriter için ayrı ayrı olmak üzere tüm sipariş yani alternatifler havuzunda yapılması sonucunda tüm kriterler 0 ve 1 aralı̆̆ında değer alarak normalizasyon işlemine tabi tutulmuş olur ve her biri aynı birim olarak değerlendirileceği karar matrisinin bir elemanı olmuş olur. Artık kriterlerin birbirine baskınlığı sadece ağırlık katsayısı oranında olacaktır. Bunun haricinde her kriter değeri diğer alternatiflerin durumuna göre 0 ile 1 aralığındaki değerini alacaktır.

Normalizasyon işleminden sonra tüm siparişler amaç fonksiyonu olan F fonksiyonuna göre küçükten büyüğe doğru sıralanır. Çünkü F bir maliyet fonksiyonudur. Maliyeti en az olan sipariş önceliklendirilerek belirlenen üretim programına siparişler kabul edilmelidir. Sıralı siparişlere Şekil 1'de işlem ayrıntılarının belirtildiği üzere birer teslim tarihi hesaplanır. Daha sonra hesaplanan teslim tarihlerinden siparişlerin talep tarihine göre daha $\mathrm{m}$ erken veya daha $\mathrm{m} ı$ geç üretileceği durumu Şekil 2'deki işlem adımlarına göre hesaplanır (Aktürk, 2018a).

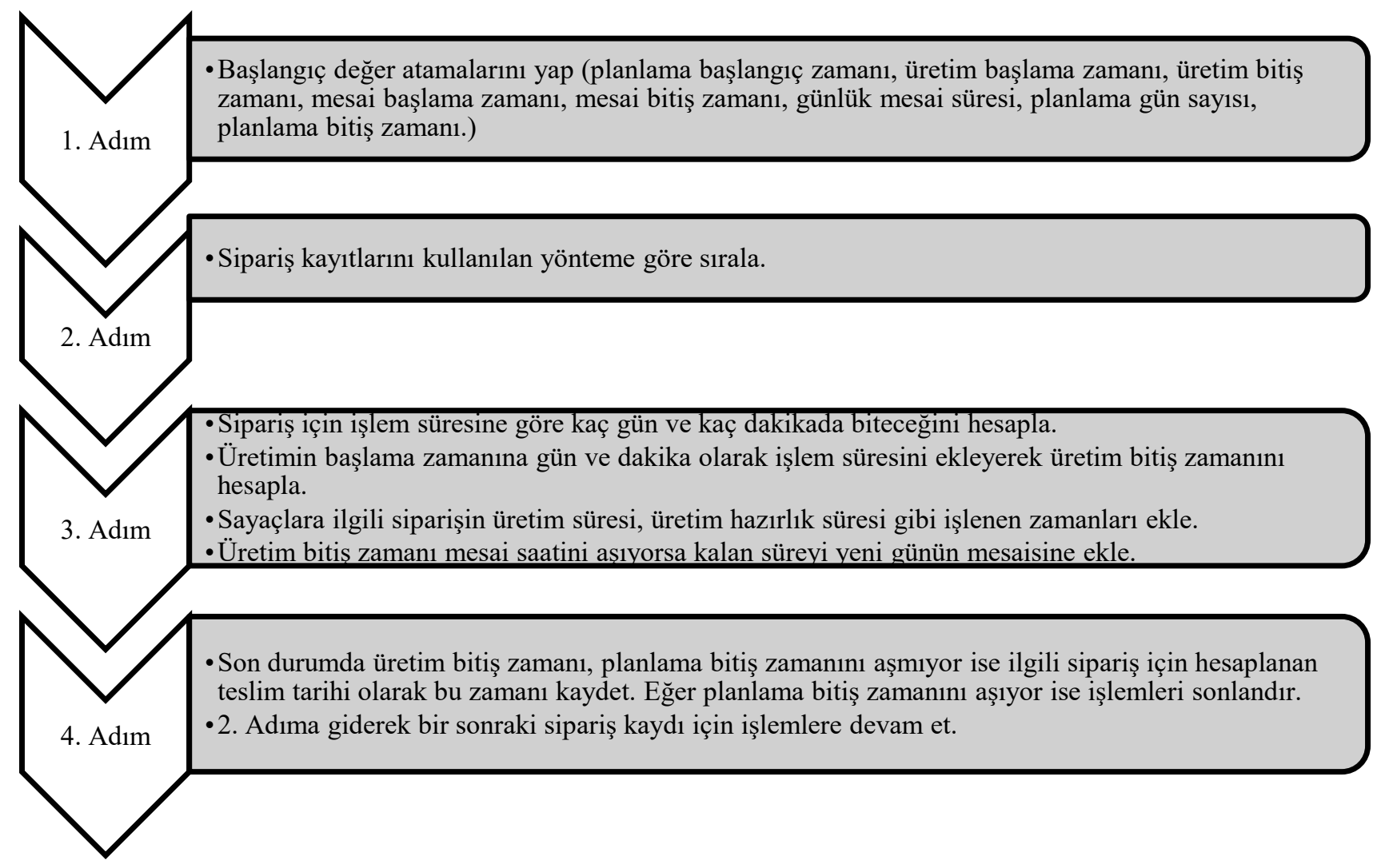

Şekil 1. Teslim Tarihi Atama Fonksiyonu (Aktürk, 2018a). 
1. Adım

- durum ve gunfarki değişkenlerine başlangıç değeri ata

(durum=" " , gunfarki=0)

2. Adim

- Her sipariş için hesaplanan ve talep edilen teslim tarihi verilerini karşılaştır.

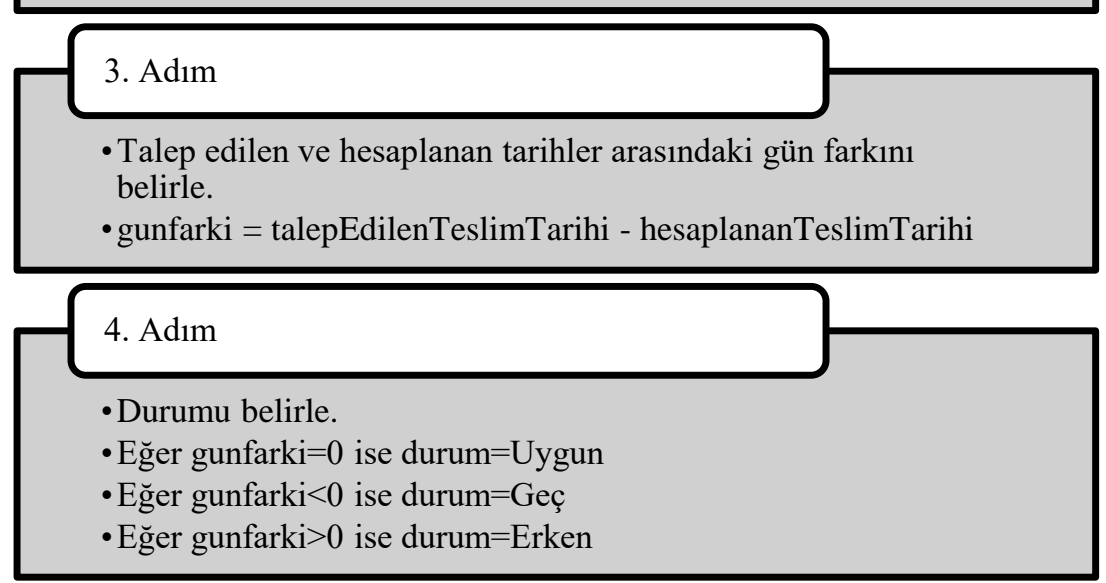

Şekil 2. Sipariş Durumu Belirleme İşlem Adımları (Aktürk, 2018a).

Yukarıda anlatılan formüller ve işlem akışlarından oluşan karar modeli herhangi bir elektronik tablo programında (Örneğin Excel) veya herhangi bir programlama dili ile geliştirilecek bir yazılım ile karar modelinden hızlıca bir karar destek sistemine dönüşmeye hazırdir.

\section{Araştırma Sonuçları ve Tartışma}

Stoğa üretim yapan işletmelerde teslim tarihi ile ilgili pek sorun yaşanmamaktadır. Çünkü genelde müşterilerin talep edeceği ürünler üreticinin stoklardan veya farklı pazarlama kaynaklarından doğrudan temin edildiğinden dolayı sadece ürün sevkinde geçen süre bulunmaktadır. Ancak özellikle siparişe göre üretim yapan işletmeler için teslim tarihi belirleme, siparişin kabul sürecinden başlayarak malzeme ihtiyaç planlaması, üretim planlaması, üretim programı ve sevkiyat süreçlerinin tamamından etkilendiği için iyi yönetilmesi gereken bir süreçtir. Önceki çalışmalara bakıldığında genel olarak siparişlerin erken veya geç kalma durumlarındaki ceza ve maliyetler çalışılmış olmakla birlikte erken üretilen siparişler için doğacak lojistik maliyetler konusunda yapılmış ayrıntılı bir çalışma bulunmamaktadır. Yapılan çalışmada önerilen karar modeli ile siparişe göre üretim yapan işletmeler için lojistik maliyetleri minimize etmelerine yol göstermek amacıyla doğrusal bir karar modeli geliştirilmiştir. Geliştirilen karar modelini baz alarak siparişleri lojistik maliyetler açısından sıralayacak karar destek sistemleri herhangi bir geliştirme ortamında programlanabilir. Ayrıca, özellikle inşaat ve yapı imalatı gibi proje tabanlı ve isteğe özel üretilen ürünler hem proje takviminde meydana gelebilecek gecikmelerden dolayı üreticiden doğru zamanda temin edilememektedir. Bu zaman belirsizliği talep edilen ürünün, müşterinin ihtiyaç duyduğu tarihten erken üretilmesi durumunda işletmelere görünmeyen ancak gerçekte mevcut olan lojistik maliyetleri yüklemektedir. Geliştirilecek karar destek sistemleri, siparişe üretim yapan firmaların satış ve pazarlama yöneticileri tarafından kullanılarak lojistik maliyetler açısından işletmelerin yüklenmek zorunda kalacakları gizli maliyetler her bir sipariş için ayrı ayrı gözlemlenebilir. Bu maliyetler daha satış işlemi öncesinden öngörülerek ürünün birim fiyatına yansıtılabilir.

Yapılan çalışma ile siparişe göre üretim yapan bir işletmeye gelen herhangi bir sipariş için kabul kararı verilmeden önce talep edilen tarihlere göre siparişler sıralanır. Sonrasında her sipariş için ilgili amaç fonksiyonu değerleri hesaplanırsa, ilgili siparişleri istenen tarihlerde teslim etmenin veya siparişleri üreterek stokta bekletmenin işletmeye getireceği maliyetler su yüzüne çıkacaktır. Buraya kadar anlatılan önceki çalışmalarda pazarlama birimi yöneticilerinin siparişleri kabul ederken lojistik maliyetleri göz önünde bulundurduğu bir karar modeline ulaşılmamıştır. Genelde yapılan çalışmalar gelirleri arttırmaya yöneliktir (Guhlic vd. 2015; Aktürk ve Gülseçen, 2018). Ya da çeşitli teorik çalışmalar ile geciken siparişlerin maliyetini azaltmak amaçlanmıştır (Jagan vd., 2015; Low vd., 2016; Çakar vd., 2015; Assarzadegan ve Barzoki, 2016; Shatbay vd., 2016; Zhao, 2016; Drwal, 2018). Önerilen karar modelinin faydası lojistik maliyetleri ortaya çıkarmakla kalmayıp, teslim tarihinde 1srarcı olan müşteriler için baştan anlaşma sağlamadan oluşacak maliyetler ürünlerin birim fiyatına yansıtılabilir veya müşteriler, üretici firmaların lojistik maliyetler olmadan hesaplayacağı teslim tarihlerini kabul etme konusunda ikna edilebilirler. 
Sonuç olarak müşteriler talep tarihlerinde 1srar ettikleri durumunda üretici firmanın yüklenmek zorunda kalacağı lojistik maliyetleri ürünlerin birim fiyatında daha sipariş kabul aşamasında yapılacak artı̧̧la ya kendileri üstlenmiş olur, ya da bu karar modellerini kullanan üretici firmaların kendilerine lojistik maliyet doğurmayacak şekilde önerecekleri teslim tarihlerini kabul etmek durumunda olurlar. Kendilerine ihtiyaç duyacakları tarihe kadar gerek duymayacakları ürünlerin fabrikalardan sevkini sağlayan müşteriler, bu ürünlerin depolanmasından ve her türlü riskinden kendileri sorumlu olacaktır. Yapılan çalışma ile ayrıca sonraki çalışmalarda geliştirilecek karar destek sistemlerine lojistik maliyetler açısından ayrı bir yol açılarak teslim tarihi literatürüne yenilik getirilmiştir. Önerilen karar modelinden oraya çıarılacak karar destek sistemleri aynı zamanda değişken ortamlarda anlık olarak ortaya çıkan tüm belirsizlikleri gidermeye yardımcı olan birer araç olduğu için endüstri 4.0 dönüşümlerinde sipariş kabulü, üretim planlama, teslim tarihi belirleme ve sevkiyat gibi iş süreçlerinin entegrasyonuna da önemli katkı sağlayacaktır.

\section{Kaynakça}

Aktürk, C, Gülseçen, S. (2017). Teslim Tarihi Problemi ve İnovatif Bir Karar Modeli Önerisi. Girişimcilik İnovasyon ve Pazarlama Araştırmaları Dergisi, 1 (2), 103-119. DOI: 10.31006/gipad.338360

Aktürk, C., \& Gülseçen, S. (2018). Sipariş Teslim Tarihi Problemi İçin Çok Kriterli ve Çok Yöntemli Karar Destek Sistemi Önerisi. Institute of Business Administration-Management Journal/Isletme Iktisadi Enstitüsü Yönetim Dergisi, 29(84).

Aktürk, Cemal. (2018), Çok Kriterli Karar Destek Modeli Ve Gelir Yaklaşımıyla Sipariş Teslim Tarihi Belirleme, Doktora Tezi, İstanbul Üniversitesi.

Assarzadegan, P., \& Rasti-Barzoki, M. (2016). Minimizing sum of the due date assignment costs, maximum tardiness and distribution costs in a supply chain scheduling problem. Applied Soft Computing, 47, 343-356.

Baker, K. R., \& Trietsch, D. (2015). Trading off due-date tightness and job tardiness in a basic scheduling model. Journal of Scheduling, 18(3), 305-309.

Ceran, Y, Alagöz, A. (2007). Lojistik Maliyet Yönetimi: Lojistik Maliyetler ve Lojistik Maliyet Muhasebesi. Yönetim Bilimleri Dergisi, 5 (2), 131-152. Retrieved from http://dergipark.gov.tr/comuybd/issue/4113/54140

Çakar, T., Köker, R., \& Canay, O. (2015). A new neuro-dominance rule for single-machine tardiness problem with double due date. Neural Computing and Applications, 26(6), 1439-1450.

Demir, H. I., Uygun, O., Cil, I., Ipek, M., \& Sari, M. (2015). Process planning and scheduling with SLK due-date assignment where earliness, tardiness and due-dates are punished. Journal of Industrial and Intelligent Information, Vol, 3(3).

Drwal, M. (2018). Robust scheduling to minimize the weighted number of late jobs with interval due-date uncertainty. Computers \& Operations Research, 91, 13-20.

Guhlich, H., Fleischmann, M., \& Stolletz, R. (2015). Revenue management approach to due date quoting and scheduling in an assemble-to-order production system. OR spectrum, 37(4), 951-982.

Jagan, D., Senthilvel, A. N., Prabhakar, R., \& Maheswari, S. U. (2015). Analysis for Maximal Optimized penalty for the Scheduling of Jobs with Specific Due Date on a Single Machine with Idle Time. Procedia Computer Science, 47, 247-254.

Li, S. S., \& Chen, R. X. (2017). Common due date assignment and cumulative deterioration scheduling on a single machine. Engineering Optimization, 49(6), 976-989.

Low, C., Li, R. K., Wu, G. H., \& Huang, C. L. (2015). Minimizing the sum of absolute deviations under a common due date for a single-machine scheduling problem with availability constraints. Journal of Industrial and Production Engineering, 32(3), 204217.

Low, C., Li, R. K., \& Wu, G. H. (2016). Minimizing total earliness and tardiness for common due date single-machine scheduling with an unavailability interval. Mathematical Problems in Engineering, 2016.

Lödding, H., \& Piontek, A. (2017). The surprising effectiveness of earliest operation due-date sequencing. Production Planning \& Control, 28(5), 459-471.

Nurainun, T., Fudholi, A., Hartati, M., Yendra, R., \& Kusumanto, I. (2016). A multi due date batch scheduling model on dynamic flow shop to minimize total production cost. Contemporary Engineering Sciences, 9(7), 315-324.

Schäfer, R., Chankov, S., \& Bendul, J. (2016). What is really "on-time"? A comparison of due date performance indicators in production. Procedia CIRP, 52, 124-129.

Shabtay, D., Steiner, G., \& Zhang, R. (2016). Optimal coordination of resource allocation, due date assignment and scheduling decisions. Omega, 65, 41-54.

Şen, İ. K. (2014). Lojistik faaliyetlerin yönetimi ve maliyetleme yaklaşımları. Çankirı Karatekin Üniversitesi İIBF Dergisi, 4(1), 83106. 
Zahedi, Z., Samadhi, T., Suprayogi, S., \& Halim, A. (2016). Integrated batch production and maintenance scheduling for multiple items processed on a deteriorating machine to minimize total production and maintenance costs with due date constraint. International Journal of Industrial Engineering Computations, 7(2), 229-244.

Zhao, C. (2016). Common due date assignment and single-machine scheduling with release times to minimize the weighted number of tardy jobs. Japan Journal of Industrial and Applied Mathematics, 33, (1), 239-249. 